\title{
HUBUNGAN PENGETAHUAN DAN SIKAP IBU DENGAN \\ PEMBERIAN ASI EKSKLUSIF DI WILAYAH KERJA \\ PUSKESMAS MELUR PEKANBARU TAHUN 2014
}

\author{
Ani Triana, Febrina Ariantika.Z \\ STIKes Hang Tuah Pekanbaru
}

\begin{abstract}
The first and main food for babies is breast milk. Breast milk contains the most complete nutritional composition and ideal for the growth and development of infants during the first 6 months. Based on Riskesdas 2012, the percentage coverage of infants who received exclusive breastfeeding until 6 months is only 15,3\%. In Riau, the scope of exclusive breastfed babies is only 70\%. This study aims to determine the relationship between knowledge and attitude of lactating mothers with exclusive breastfeeding in infants aged $>6-12$ months.

The type of this research is analytic survey with cross sectional approach. The total samples in this study were 64 lactating mothers who had babies aged >6-12 months in the working area of Puskesmas (Health Center) Melur Pekanbaru taken using purposive sampling technique according to criteria. Collecting data through interviews using a questionnaire. The statistical test used to analyze the relationship between variables using chi square.

The results showed that most respondents $(73,4 \%)$ had good knowledge, had 57,8\% agood attitude and just $28,1 \%$ of respondents who are exclusively breastfed.

The results of data analysis showed no significant relationship between knowledge and exclusive breastfeeding $(p=0.279)$ and there is a relationship between attitudes to exclusive breastfeeding $(p=0.610)$.

Expected can improve health energy participation in giving information about ASI Ekslusif, by performing a counselling to mother, so that a period of/to to come knowledge of mother will progressively mount and important realizing of him ASI Ekslusif.
\end{abstract}

Keyword : exclusive breastfeeding, knowledge, attitude.

\begin{abstract}
ABSTRAK
Makanan pertama dan utama bagi bayi adalah air susu ibu (ASI). ASI mengandung komposisi gizi yang paling lengkap dan ideal untuk pertumbuhan dan perkembangan bayi selama 6 bulan pertama. Berdasarkan Riskesdas 2012, persentase cakupan bayi yang mendapat ASI eksklusif sampai dengan 6 bulan hanya 15,3\%, di Riau cakupan bayi yang mendapat ASI eksklusif hanya $70 \%$. Penelitian ini bertujuan untuk mengetahui hubungan antara pengetahuan dan sikap ibu dengan pemberian ASI eksklusif pada bayi usia >6-12 bulan.

Jenis penelitian ini adalah survey analitik dengan pendekatan cross sectional.Jumlah sampel dalam penelitian ini adalah sebanyak 64 ibu menyusui yang mempunyai bayi usia >6-12 bulan di wilayah Kerja Puskesmas Melur Pekanbaru yang diambil dengan menggunakan teknik purposive sampling sesuai kriteria.

Hasil penelitian menunjukkan bahwa sebagian besar responden $(73,4 \%)$ memiliki pengetahuan baik, $57,8 \%$ mempunyai sikap baik dan hanya $28,1 \%$ responden yang
\end{abstract}


memberi ASI secara eksklusif. Hasil analisis data menunjukkan tidak ada hubungan bermakna antara pengetahuan dan pemberian ASI eksklusif $(\mathrm{p}=0,279)$ dan tidak ada hubungan antara sikap dengan pemberian ASI eksklusif $(\mathrm{p}=0,610)$.

Diharapkan tenanga kesehatan agar dapat berkunjung kerumah-rumah ibu yang mempunyai bayi sehingga dapat meningkatkan cakupan pemberian ASI Ekslusif pada bayi yang mana sangat banyak manfaatnya bukan hanya untuk Bayi tapi juga bemanfaat untuk Ibunya.

Kata Kunci $\quad$ : ASI Eksklusif, Pengetahuan, Sikap

\section{PENDAHULUAN}

ASI Eksklusif didefinisikan sebagai pemberian ASI kepada bayi sampai dengan 6 bulan secara langsung oleh ibunya dan tidak diberikan makanan cair atau padat lainnya kecuali obat tetes atau sirup yang berisi suplemen vitamin, mineral, atau obat (Rachmadewi, Dkk, 2009).

ASI Eksklusif adalah bayi hanya diberi ASI, saja selama 6 bulan, tanpa tambahan cairan lain seperti susu formula, jeruk, madu, air teh serta tanpa makanan padat seperti pisang, bubur susu, biscuit, bubur nasi, dan nasi tim, setelah 6 bulan baru diberikan makanan pendamping ASI (Kristiyanasari, 2011).

\section{Rekomendasi World Health} Organization (WHO) pada pertemuan tahun 1979 di Geneva tentang makanan bayi dan anak antara lain berisi: “ menyusukan merupakan bagian terpadu dari proses reproduksi yang memberikan makanan bayi secara ideal dan alamiah serta merupakan dasar biologi dan psikologi yang dibutuhkan untuk pertumbuhan ". Memberikan susu formula sebagai tambahan dengan dalih apa pun pada bayi baru lahir harus dihindarkan (Prawirohardjo, 2007). Rendahnya pemberian ASI eksklusif di kalangan ibu dapat diasumsikan penyebabnya adalah kurang baik perilaku kesehatan seseorang (Komara, 2010).

$$
\text { Rendahnya pemberian }
$$

Eksklusif oleh ibu menyusui di Indonesia disebabkan oleh faktor internal dan eksternal. Faktor internal meliputi rendahnya pengetahuan dan sikap ibu,dan faktor eksternal meliputi kurangnya dukungan keluarga, masyarakat, petugas kesehatan maupun pemerintah, gencarnya promosi susu formula, faktor sosial budaya serta kurangnya ketersediaan fasilitas pelayanan kesehatan ibu dan anak (Yulianah, 2013). Tingginya angka kematian bayi di Indonesia disebabkan oleh beberapa faktor diantaranya faktor penyakit infeksi dan kekurangan gizi sedangkan penyebab lainnya adalah berbagai penyakit yang sebenarnya dapat dicegah salah satunya dengan cara 
memberikan ASI secara eksklusif (Elinofia, Dkk, 2011 ).

Para pemangku kepentingan bidang kesehatan menyimpulkan bahwa sebab dasar rendahnya cakupan ASI Eksklusif adalah akses bayi terhadap ASI Eksklusif yang rendah. Akses yang rendah tersebut sangat dipengaruhi oleh potensi spesifik ibu sebagai figur utama, yaitu perilaku ibu (Yulianah, 2013). Dalam Elinofia, Dkk (2011), Rohani (2007) juga menyatakan keberhasilan pemberian ASI terutama ASI eksklusif kepada bayi dapat dipengaruhi oleh faktor pekerjaan, sikap, dan pengetahuan ibu menyusui.

Berdasarkan data UNICEF hanya 3\% ibu yang memberikan ASI Ekslusif dan Berdasarkan Survei Demografi Kesehatan Indonesia (SDKI) 2012, hanya $27,1 \%$ bayi yang memperoleh ASI ekslusif selama 6 bulan. Sedangkan pemberian ASI pada bayi usia 0-1 bulan sebesar 50,8\%, antara usia 233 bulan sebesar 48,9\% dan pada usia 739 bulan sebesar $4,5 \%$. Pemberian ASI ekslusif kepada bayi selama 6 bulan dalam SDKI 2012 lebih tinggi dibandingkan dengan hasil SDKI 2007 (Mursyida, 2013).

Di Propinsi Riau Cakupan pemberian ASI Eksklusif pada bayi usia 0-6 bulan pada tahun 2012 sebesar 46,2\% meningkat dibandingkan tahun 2011 sebesar 45,9 \%. Sedangkan cakupan pemberian ASI Eksklusif menurut
Kabupaten/kota tertinggi adalah cakupan Kota Dumai sebesar 61,3\%, Kabupaten Pelalawan sebesar $54,5 \%$ dan Kota Pekanbaru sebesar 54,2\%. Capaian terendah adalah Kabupaten Kampar $39,0 \%$, Kabupaten Siak sebesar 39,5\% dan Kabupaten Bengkalis sebesar 40,9\%. Untuk cakupan pemberian ASI Eksklusif ini baik secara Provinsi maupun kabupaten/kota masih dibawah target renstra sebesar 70\% ( Profil Kesehatan, 2012).

Pencapaian cakupan pemberian ASI Eksklusif di Kota Pekanbaru berdasarkan laporan Dinas Kesehatan Kota Pekanbaru tahun 2012 adalah dari 20 puskesmas didapatkan 4 puskesmas bayi yang sedikit mendapatkan ASI ekslusif yaitu Senapelan $37.41 \%$, Sail $43.41 \%$, Payung Sekaki 53.58\%, Melur 18.26\%, dari 4 puskesmas persentasi yang terendah memberikan ASI eksklusif di Puskesmas Melur.

Berdasarkan latar belakang diatas maka penulis tertarik melakukan penelitian untuk mengetahui " Hubungan Pengetahuan dan sikap Ibu Dengan Pemberian ASI Eksklusif di Wilayah Kerja Puskesmas Melur Tahun 2014”.

\section{METODOLOGI}

Penelitian ini dilakukan dengan menggunakan metode penelitian analtik analitik kuantitatif dengan desain 
penelitian "Cross Sectional" yaitu variabel independen dengan variabel dependen diteliti dengan bersamaan untuk mengetahui Hubungan Pengetahuan dan Sikap Ibu Dengan Pemberian ASI Ekslusif di Wilayah Kerja Puskesmas Melur Tahun 2014.

Penelitian ini di laksanakan di Wilayah Kerja Puskesmas Melur Tahun 2014, dilaksanakan pada Tanggal 12 Mei sampai dengan 9 Juni 2014.

Populasi pada penelitian ini adalah ibu-ibu yang mempunyai bayi $>6$ bulan di Wilayah Kerja Puskesmas Melur Tahun 2014 yang berjumlah 192 Bayi. Cara Pengambilan sampel ini adalah dengan mengambil sebagian populasi untuk dijadikan sampel, Besar sampel dalam penelitian ini 64 orang.

Pada penelitian ini menggunakan Purposive sampling yaitu didasarkan pada HASIL

Univariat

Karakteristik Rensponden suatu pertimbangan tertentu yang dibuat oleh peneliti sendiri berdasarkan ciri atau sifat-sifat populasi yang sudah diketahui sebelumnya. Data yang diperoleh secara manual, setelah data terkumpul kemudian di olah. Dalam pengumpulan data pada penelitian digunakan alat berupa kuesionar. Kuesioner adalah sejumlah pertanyaan tertulis yang digunakan untuk memperoleh informasi dalam arti laporan tentang pribadinya atau hal-hal yang diketahuinya (Notoatmodjo, 2010). Analisis univariat dilakukan dengan melihat distribusi frekuensi masingmasing katagori variabel. Analisis bivariat menggunakan uji Chi Square $\left(x^{2}\right)$ dengan derajat kepercayaan 95\%, Jika $p \geq 0,05$ maka dikatakan bemakna dan melihat OR (Odds Ratio).

Tabel 2

Distribusi Frekuensi Berdasarkan Karakteristik Rensponden Di Wilayah Kerja Puskesmas Melur Pekanbaru Tahun 2014

NO Variabel $\quad$ Frekuensi $\quad$ Persentase ( \% )

1 Pendidikan Terakhir Rendah (SD, SMP) $26 \quad 40.6$ Tinggi (SMA , PT) $\quad 38 \quad 59.3$

\section{Umur}

$<35$

$>35$ 


\section{Anak Keberapa}

$\begin{array}{lll}1-3 & 54 & 84.4\end{array}$

4-5 $10 \quad 15.6$

4 Memberikan ASI Ekslusif $\begin{array}{lll}\text { Iya } & 18 & 28.1\end{array}$

$\begin{array}{lll}\text { Tidak } & 46 & 71.9\end{array}$

5 Pengetahuan

$\begin{array}{lll}<5 & 17 & 26.6\end{array}$

$\begin{array}{lll}\geq 5 & 47 & 73.4\end{array}$

6 Sikap

$\begin{array}{lll}<30 & 27 & 42.2\end{array}$

$\geq 30 \quad 37 \quad 57.8$

Berdasarkan Tabel 2 dapat diketahui Bivariat

bahwa mayoritas Pendidikan terakhir Analisis bivariat dilakukan untuk melihat rensponden SD dan SMP yaitu 40,6\%, apakah ada hubungan pengetahuan dan rensponden umur terbanyak >35 tahun sikap ibu dengan pemberian ASI Ekslusif. sebanyak 59 orang yaitu $92,2 \%$, memiliki jumlah anak 1-3 Orang anak sebanyak 54 yaitu $84,4 \%$,

\section{a. Hubungan Pengetahuan dengan} Pemberian ASI Ekslusif

yang tidak memberika ASI Ekslusif 71,9\%, memiliki pengetahuan yang kurang tentang ASI Ekslusif sebanyak 26,6\%, memiliki sikap negatif yaitu sebanyak $42,2 \%$.

Tabel 3

Hubungan Pengetahuan dengan Pemberian ASI Ekslusif Di Wilayah Kerja Puskesmas Melur Kota Pekanbaru Tahun 2014

\begin{tabular}{|c|c|c|c|c|c|c|c|c|}
\hline \multirow[t]{3}{*}{ Pengetahuan } & \multicolumn{4}{|c|}{ ASI Ekslusif } & & & \multirow{3}{*}{$\begin{array}{c}P \\
\text { Value }\end{array}$} & \multirow{3}{*}{$\begin{array}{c}Q R \\
(95 \% \mathrm{CI})\end{array}$} \\
\hline & \multicolumn{2}{|c|}{ Tidak } & \multicolumn{2}{|l|}{ Iya } & \multicolumn{2}{|c|}{ Jumlah } & & \\
\hline & $\mathbf{n}$ & $\%$ & $\mathrm{n}$ & $\%$ & $\mathrm{n}$ & $\%$ & & \\
\hline Kurang & 7 & $41.2 \%$ & 10 & $58.8 \%$ & 17 & 100 & & 2.291 \\
\hline Baik & 11 & $23.4 \%$ & 36 & $76.6 \%$ & 47 & 100 & 0.279 & $(0.759-7.444)$ \\
\hline
\end{tabular}

Berdasarkan Tabel 3 dapat dari 17 orang (41,2\%), dan ibu yang memberikan rensponden yang memiliki pengetahuan ASI Ekslusif sebanyak 10 orang (58,8\%). kurang tidak memberikan ASI Ekslusif 7 Sedangkan dari 47 rensponden memiliki 
pengetahuan baik tidak memberikan ASI Ekslusif 11 rensponden $(23,4 \%)$ dan ibu yang memberikan ASI Ekslusif sebanyak 36 orang (76,6). Hasil uji Chi-Square menunjukkan nilai $P$ value $=0,279$ $(p \leq 0,05)$ yang berarti Tidak ada hubungan yang bermakna antara Pengetahuan ibu dengan Pemberian ASI Ekslusi di Wilayah Kerja Puskesmas Melur Pekanbaru.

b. Hubungan Sikap dengan Pemberian ASI Ekslusif

\section{Tabel 4}

\section{Hubungan Sikap dengan Pemberian ASI Ekslusif Wilayah Kerja Puskesmas Melur Pekanbaru Tahun 2014}

\begin{tabular}{|c|c|c|c|c|c|c|c|c|c|}
\hline \multirow[t]{3}{*}{ Sikap } & \multicolumn{5}{|c|}{ ASI Ekslusif } & & & \multirow{3}{*}{$\begin{array}{c}P \\
\text { Value }\end{array}$} & \multirow{3}{*}{$\begin{array}{l}\text { OR } \\
(95 \% \mathrm{CI})\end{array}$} \\
\hline & \multicolumn{3}{|c|}{ Tidak } & \multicolumn{2}{|c|}{ Iya } & \multicolumn{2}{|c|}{ Jumlah } & & \\
\hline & $\mathbf{n}$ & $\%$ & $\mathrm{n}$ & $\%$ & $\mathbf{n}$ & $\%$ & & & \\
\hline Negatif & 9 & & 33,3 & 18 & 66,7 & 27 & 100 & & 1,556 \\
\hline Positif & 9 & & 24,3 & 28 & 75,7 & 37 & 100 & 0,610 & $(0,519-4,661)$ \\
\hline
\end{tabular}

Berdasarkan table 4 dapat dari 27 rensponden yang memiliki sikap negatif, ibu yang tidak memberikan ASI Ekslusif sebanyak 9 orang $(33,3 \%)$ dan ibu yang memberikan ASI Ekslusif sebanyak 18 orang (67,9\%), sedangkan dari 37 rensponden yang memiliki sikap positif, ibu yang tidak memberikan ASI Ekslusif sebanyak 9 orang $(24,3 \%)$ dan ibu yang memberikan ASI Ekslusif sebanyak 28 orang (75,7\%). Hasil uji Chi-Square menunjukkan nilai $P$ value $=0,610$ $(p \leq 0,05)$ yang berarti Tidak ada hubungan yang bermakna antara sikap ibu dengan pemberian ASI Ekslusif.

\section{PEMBAHASAN}

Hubungan Pengetahuan Ibu dengan Pemberian ASI Ekslusif di Wilayah Kerja Puskesmas Melur Pekanbaru Tahun 2014.

Berdasarkan hasil Analisis yang telah dilakukan diketahui bahwa pengetahuan ibu terhadap pemberian ASI Ekslusif di Wilayah Kerja Puskesmas Melur Pekanbaru tahun 2014 dari 17 rensponden yang memiliki pengetahuan kurang tidak memberikan ASI Ekslusif 7 orang $(41,2 \%)$, dan ibu yang memberikan ASI Ekslusif sebanyak 10 orang $(58,8 \%)$. 
Sedangkan dari 47 rensponden memiliki pengetahuan baik tidak memberikan ASI Ekslusif 11 rensponden $(23,4 \%)$ dan ibu yang memberikan ASI Ekslusif sebanyak 36 orang $(76,6)$. Hasil uji Chi-Square menunjukkan nilai $P$ value $=0,279$ $(p \leq 0,05)$ yang berarti Tidak ada hubungan yang bermakna antara Pengetahuan ibu dengan Pemberian ASI Ekslusi di Wilayah Kerja Puskesmas Melur Pekanbaru.

Hal ini sesuai dengan teori yang mengatakan Pengetahuan yang baik dari ibu tentang ASI Eksklusif akan berpengaruh terhadap perilaku ibu dalam memberikan ASI Eksklusif kepada bayinya. Ibu yang mempunyai pengetahuan yang baik tentang ASI Eksklusif mempunyai kemungkinan yang lebih besar dalam memberikan ASI secara Eksklusif kepada bayinya sampai usia 0 6 bulan tanpa pemberian makanan tambahan (Komara, 2010).

Hasil penelitian ini sejalan dengan hasil penelitian yang dilakukan oleh Yulianah (2013) Di Wilayah Kerja Puskesmas Bonto Cani Kabupaten Bone menunjukkan bahwa sebagian besar responden $(64,4 \%)$ memiliki pengetahuan ASI Eksklusif dalam kategori kurang dan tidak terdapat hubungan bermakna antara pengetahuan responden dengan pemberian ASI Eksklusif $(\mathrm{p}=1,132)$.
Menurut peneliti ibu yang berpengetahuan baik mereka memberikan ASI Ekslusif. sesuai dengan teori yang mengatakan ibu yang mempunyai pengetahuan baik akan memberikan ASI Ekslusif, tetapi peneliti mendapatkan tidak ada hubungan antara pengetahuan dengan pemberian ASI Ekslusif dikarenakan salah satunya sampel yang sedikit

\section{Hubungan Sikap dengan Ibu dengan pemberian ASI Ekslusif di Wilayah Kerja Puskesmas Melur Pekanbaru Tahun 2014.}

Berdasarkan table 4 dapat dari 27 rensponden yang memiliki sikap negatif, ibu yang tidak memberikan ASI Ekslusif sebanyak 9 orang $(33,3 \%)$ dan ibu yang memberikan ASI Ekslusif sebanyak 18 orang (67,9\%), sedangkan dari 37 rensponden yang memiliki sikap positif, ibu yang tidak memberikan ASI Ekslusif sebanyak 9 orang $(24,3 \%)$ dan ibu yang memberikan ASI Ekslusif sebanyak 28 orang $(75,7 \%)$. Hasil uji Chi-Square menunjukkan nilai $P$ value $=0,610$ $(p \leq 0,05)$ yang berarti Tidak ada hubungan yang bermakna antara sikap ibu dengan pemberian ASI Ekslusif.

Hal ini sesuai dengan teori yang menjelaskan bahwa sikap mempunyai tiga komponen yaitu kepercayaan atau ide dan konsep terhadap suatu objek, evaluasi 
terhadap suatu objek dan kecenderungan untuk bertindak ketiga komponen ini akan membentuk suatu sikap (Candrias, 2010).

Hasil penelitian ini sejalan dengan hasil penelitian yang dilakukan oleh Yulianah (2013) Di Wilayah Kerja Puskesmas Bonto Cani Kabupaten Bone, Hasil penelitian menunjukkan bahwa sebagian besar responden $(71,15 \%)$ memiliki sikap negatif terhadap ASI Eksklusif dan tidak terdapat hubungan yang bermakna antara sikap responden dengan pemberian ASI Eksklusif $(\mathrm{p}=$ $0,154)$.

Menurut peneliti sikap responden tidak memiliki hubungan yang bermakna dengan pemberian ASI Ekslusif dikarenakan sampel yang sedikit, tetapi data menunjukkan bahwa responden yang memiliki sikap yang positif cenderung memberikan ASI Ekslusif, dibanding responden yang memiliki sikap yang negatif. Hal ini disebabkan karena masih ada kepercayaan dari ibu dan keluarga bahwa pemberian makanan tambahan selain ASI dapat diberikan sedini mungkin sehingga bayi cepat besar tanpa mengetahui efek dari pemberian makanan selain ASI pada bayi usia dibawah 6 bulan.

\section{KESIMPULAN}

Berdasarkan hasil penelitian tentang hubungan pengetahuan dan sikap ibu dengan pemberian ASI Ekslusif di Wilayah Kerja Puskesmas Melur Pekanbaru 2014 dapat ditarik kesimpulan. Tidak ada hubungan yang bermakna antara Pengetahuan Ibu dengan pemberian ASI Ekslusif di Wilayah Kerja Puskesmas Melur Pekanbaru. Tidak Ada hubungan yang bermakna antara Sikap Ibu dengan pemberian ASI Ekslusif di Wilayah Kerja Puskesmas Melur Pekanbaru.

\section{SARAN}

\section{Bagi Masyarakat}

Diharapkan Ibu dapat menerapkan pengetahuan dan sikap terhadap informasi tentang penting nya ASI Ekslusif melalui media massa, alat elektronik seperti televisi, radio, majalah, surat kabar, buku bacaan dan penyuluhan-penyuluhan dari tenaga kesehatan dan melakukan konseling langsung dengan tenaga kesehatan.

\section{Bagi Peneliti Selanjutnya}

$$
\text { Hendaknya untuk peneliti }
$$
selanjutnya dilakukan di Puskesmas agar dapat menambah variable lain seperti ( Dukungan keluarga, pekerjaan dan lainlain).

\section{Bagi Institusi Pendidikan}

Diharapkan Institusi Pendidikan dapat mengadakan pengabdian masyarakat tentang Pemberian ASI 
Ekslusif yang dilakukan baik oleh masyarakat atau bersama dengan dosen.

\section{DAFTAR PUSTAKA}

Azwar, A, (2008). Sikap Manusia Teori dan Pengukurannya. Yogyakarta: Pustaka Pelajar Offset.

Candriasih.(2010).file:///F:/Hubungan_Pe ngetahuan_Sikap_Ibu_Tentang_Asi _Eksklusif_Dengan_Praktek_Pembe rian_Asi_Ekslusif_Di_Rumah_Sakit _Bersalin_SeKecmatan_Sragen_Ka bupaten_Sragen_Diponegoro_Uni versity__Institutional_Repository_ \%28UNDIP-IR\%29.htm, diakses 3 Juli 2014.

Diah, 2012, Pro ASI Eksklusif. Tegakkan UU Pengaturan Susu Formula(http://jurnalbidandiah.blog spot.com/2012/05/pro-asi eksklusif tegakkan-uu_01.html, diakses 27 februari 2014)

Elinofia, Dkk. ( 2011). Xfile:///D:/Hubungan\%20Pendidika n,\%20Pengetahuan, \%20Pekejaan, \% 20Dan\%20Dukungan\%2Keluarga\% 20Dengan\%20emberian\%20ASI\%2 OEkslusif\%20Di\%20Puskesmas\%20 Sawah\%20embar\%20Kota\%20Beng kulu20Tahun\%202011\%20\%28Elin ofia,\%20Rita\%20Doveriyanti,\%20R oma\%20Ulina\%29.htm, diakses 4februari 2014
Hidayat, A.A. (2011). Riset Keperawatan Dan Teknik Penulisan Ilmiah. Jakarta: Rineka Cipta .

Kristiyan1asari, W. (2011). ASI Menyusui \& Sadari. Yogyakarta: Nuha Medika.

Komara, A . (2010), Hubungan Antara Pengetahuan Dan Sikap Ibu Tentang ASI Ekslusif Dengan Pemberian ASI Ekslusif. (http://duniabagikita.blogspot.com/2 $\underline{010 / 05}$ /hubungan-antarapengetahuan-dan-sikap.html, diakses 4 februari 2014).

Mursyida

A.

(2013).http://poltekkespalembang.ac .id/userfiles/files/hubungan _umur_ibu_dan_paritas_dengan_pe mberian_asi_eksklusif_pada_bayi_b erusia_0.pdf, diakses 28 februari 2014.

Yulianah, N. (2013), Hubungan Antara Pengetahuan, Sikap Dan Kepercayaan Ibu Dengan Pemberian ASI Ekslusif Di Wilayah Kerja Puskesmas Bonto Cani Kabupaten Bone Tahun 2013(http://repository.unhas.ac.id/bi tstream/handle/123456789/5560/JU $\underline{\text { RNAL.pdf?sequence }=\text {,diakses }} 4$ februari 2014).

Nurulsalam. (2008). Konsep penerapan metodologi penelitian ilmu 
keperawatan. Surabaya: Selemba Medika .

Notoatmodjo, S. (2003). Pendidikan dan Perilaku Kesehatan. Jakarta: Rineka Cipta . (2007). Promosi Kesehatan Dan Ilmu Prilaku. Jakarta: Rineka Cipta . (2010). Metodologi penelitian. Jakarta: Rineka Cipta . (2005). Metodologi penelitian Kesehatan. Jakarta: Rineka Cipta .

Rachmadewi, A, Khomsan A, (Eds). (2009). Jurnal Gizi dan Pangan. Bogor, diakses 4 Febuari 2014

Rianto, A. (2011). Aplikasi Metodologi Penelitian Kesehatan. Yogyakata: Nuha Medika .

Rusilanti, (Eds). (2013). Gizi Terapan. Bandung:PT Remaja Rosdakarya.

Subur, W. \& Dian, A. (Eds) . Jurnal Kedokteran Muhammadiyah,
Volume 1, Nomor 1, Tahun 2012, diakses 4 februari 2014.

Sulistyowati, S. L , Majalah Informasi dan Kesehatan Promosi Kesehatan, edisi 3. (2010): Pusat Promosi Kesehatan Kementrian Kesehatan Republik Indonesia.

Proverawati, A. (2012). Prilaku Hidup Bersih Dan Sehat (PHBS). Yogyakarta: Nuha Medika.

Prawirohardjo, S. (2007). Ilmu Kebidanan. Jakarta: Yayasan Bina Pustaka.

Wulandari, S, Komariah, M, ( Eds). (2009). Hubungan Pengetahuan Dan Sikap Dengan Pemberian ASI Eksklusif Oleh ibu-ibu Yang Bekerja Sebagai Perawat Di RS.AL-Islam Kota Bandung, diakses 4 Februari 2014. 